\title{
Migration of Greylag Geese Anser anser according to recoveries of birds marked with traditional leg-rings in Sweden
}

\author{
Flyttning hos grågäss enligt återfynd av fåglar märkta med traditionella \\ metallringar i Sverige
}

LEIF NILSSON

\begin{abstract}
Traditional recoveries of ringed Greylag Geese Anser anser from different regions in Sweden have been analyzed to compare the migration patterns from a number of different areas. During the years up to and including 2012, 7210 Greylag Geese were marked with metal rings from the Swedish Ringing Centre, yielding 1398 recoveries. After exclusion of local recoveries in the ringing area, 924 recoveries were used in the present analysis. The majority of recoveries were from the Western European flyway along the Atlantic coast but some Greylag Geese marked in the province of Södermanland migrated south

through Eastern Europe even reaching Northern Africa. A number of records of Greylag Geese marked during the moult on Gotland were probably recruited from Eastern Europe. Later about $25 \%$ of these birds migrated south through central Europe. In general, the geese marked in different parts of the country showed the same migration patterns as geese neck-banded in SW Scania and Södermanland.

Leif Nilsson, Department of Biology, Biodiversity, Ecology Building, SE- 22362 Lund, Sweden.E-mail: leif.nilsson@, biol.lu.se
\end{abstract}

Received 5 September 2017, Accepted 15 October, Editor: Sören Svensson

\section{Introduction}

Starting in the early 1980s, the migration of Greylag Geese Anser anser in Europe has been intensively studied using neck-banded individuals. In Sweden, neck-banding mainly occurred in SW Scania and Öster-Malma in Södermanland with only small numbers elsewhere (Andersson et al. 2001). These data are thus biased to represent a few major marking areas, and a long series is available only from SW Scania (1984-2009; Nilsson \& Kampe-Persson in prep.).

Over the years, a large number of Greylag Geese have been ringed at different sites with traditional legrings from the Swedish Bird Ringing Centre. These recoveries, up to and including 1995, were analyzed by Fransson \& Pettersson (2001). In the present contribution, I expand the analysis to include all leg-ring recoveries up to and including 2012. As the sites of neck-banding and leg-banding are rather different, special emphasis is on whether there is a difference in migration patterns given by the two categories of recoveries

\section{Material}

The total number of Greylag Geese ringed in Sweden from the start of the ringing program up to and including 2012 was 7210, with a recovery rate of $19,4 \%$ (1398 individuals). This is almost twice as many as in the previous analysis. The main marking districts used in this analysis are shown in Figure 1. Excluding local recoveries, the numbers available for analysis of the migration patterns over major marking areas (Figure 1) is as follows: Scania 350, Gotland 245, Småland 25, Västra Götaland 38, Södermanland 158, Stockholm archipelago 23, Hälsingland 68 and Jämtland 17. For marking places before year 1995, see also Fransson \& Pettersson (2001).

\section{Results}

Of the 924 recoveries of Greylag Geese available for the present study (excluding local recoveries), 157 were reported from Sweden (Figure 2). Most foreign recoveries were from the Western European flyway following the Eastern Atlantic coast (Andersson et 


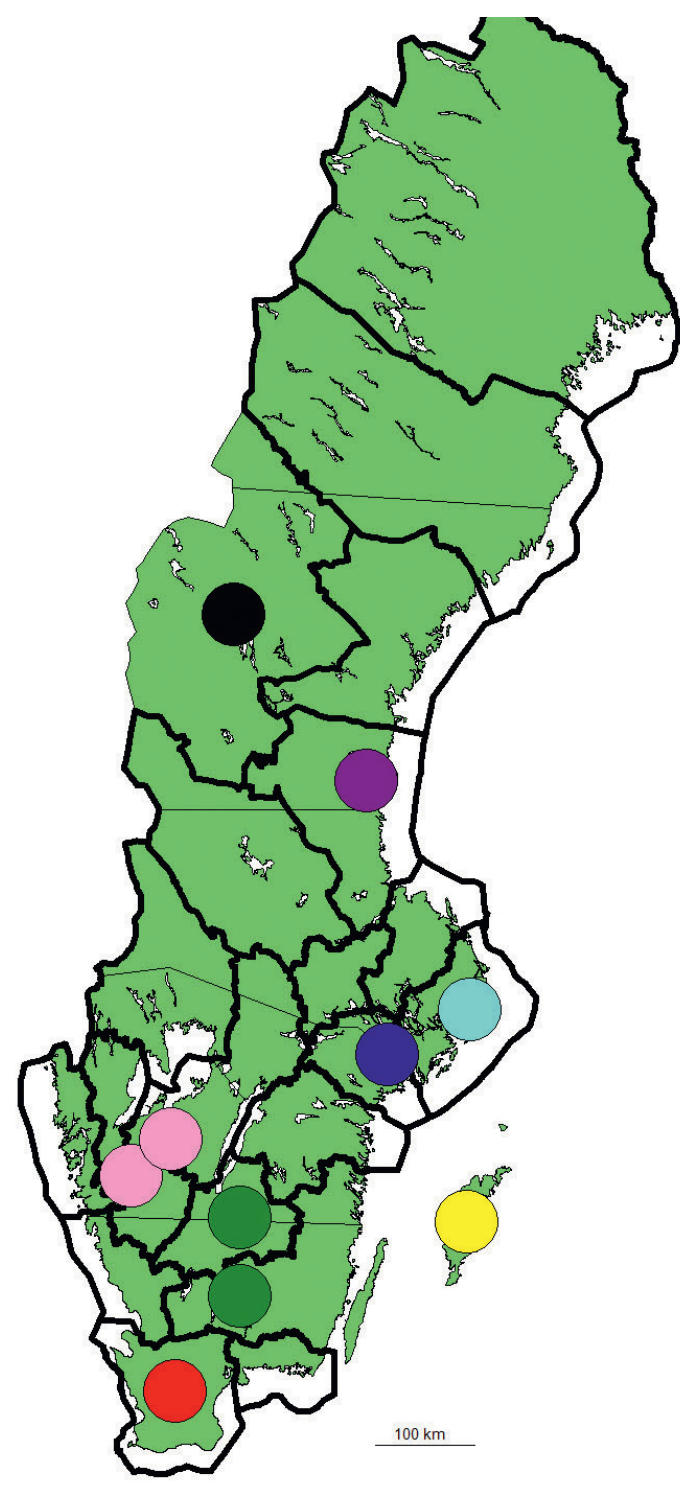

Figure 1. Map of Sweden showing counties where traditional ringing of Greylag Geese Anser anser in larger numbers has been undertaken. Colour show the colour used in the recovery maps for different counties.

Karta över Sverige och de län där större antal grågäss märkts. Färgerna visar de färger som använts $i$ återfyndskartorna för olika län.

al. 2001). In addition to recoveries from these countries, 21 recoveries were reported from Poland and between 1 and 8 recoveries came from 15 other countries. Note that there were only small differences in the number of recoveries reported from the different

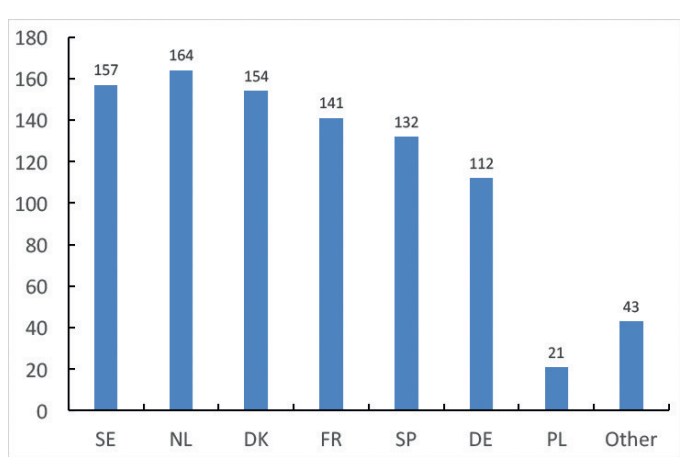

Figure 2. Number of recoveries (excluding local recoveries) of Swedish ringed Greylag Geese Anser anser reported from different countries.

Antal återfynd (exkl. lokala återfynd) av svenskmärkta grågäss från olika länder.

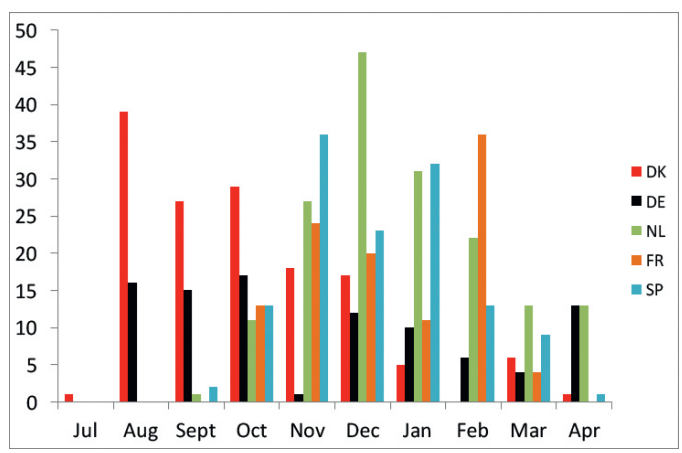

Figure 3. Monthly distribution of recoveries of Greylag Geese Anser anser marked in Sweden from some countries. Månadsfördelning av återfynd av svenskmärkta grågäss från några olika länder.

countries along the Western flyway south of Sweden. This is in marked contrast with the geographical pattern of neckband readings, where the Netherlands dominate markedly (Andersson et al. 2001). These differences are related to the number of bird-watchers reading neckbands in the different countries and to differences in hunting pressure.

The temporal pattern of the recoveries show marked variation between different countries, being related to the timing of migration and not least the differences in hunting seasons (Figure 3). In general, the leg-ring recoveries show quite good similarities with the temporal pattern of the migration as shown by the observations of neck-banded geese.

Recoveries of Greylag Geese marked in Scania (Figure 4A) are markedly concentrated to the Western flyway following the east Atlantic coast with recoveries all the way from Sweden to southern Spain, i.e. they show the same general migration pattern as 
$4 \mathrm{~A}$

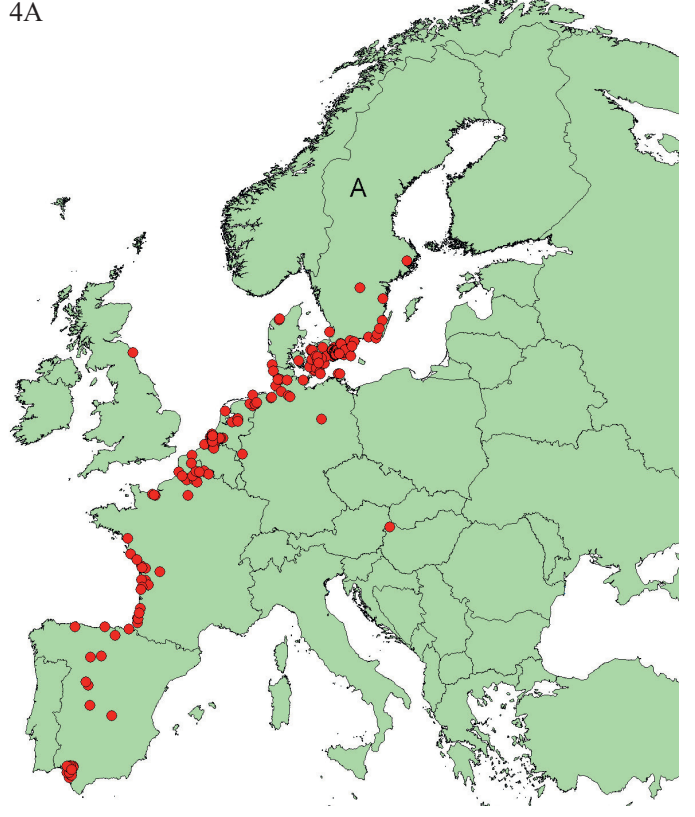

4B

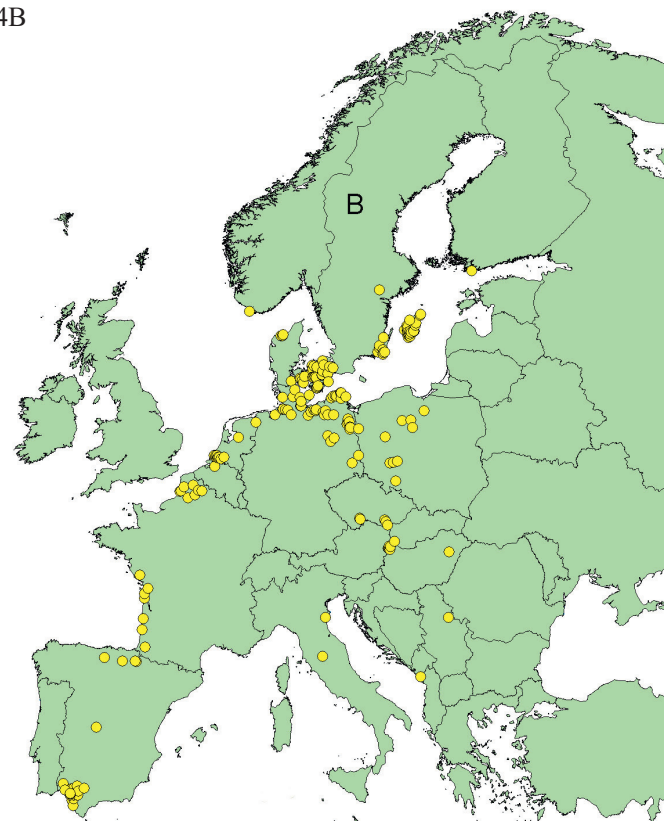

Figure 4. Recoveries of Greylag geese Anser anser marked in different parts of Sweden (see Figure 1). $\mathrm{A}=$ Skåne, $\mathrm{B}=$ Gotland, $\mathrm{C}=$ Småland, $\mathrm{D}=$ Västra Götaland, $\mathrm{E}=$ Södermanland, $\mathrm{F}$ = Stockholm archipelago, $\mathrm{G}=$ Hälsingland and $\mathrm{H}=$ Jämtland. Not shown on the map are two recoveries of birds from Gotland found in Tunisia and one from Södermanland found in Algeria.
$4 \mathrm{C}$

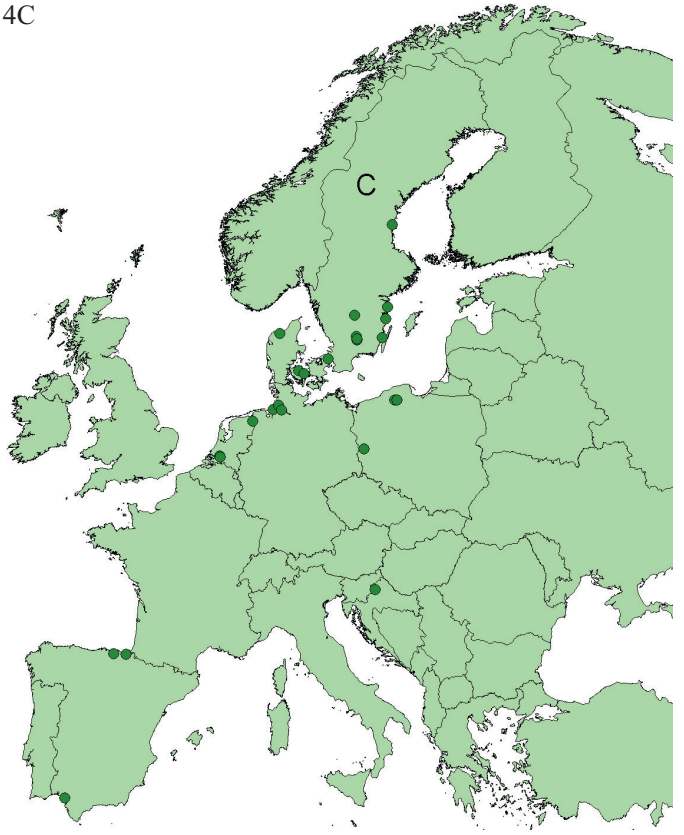

4D

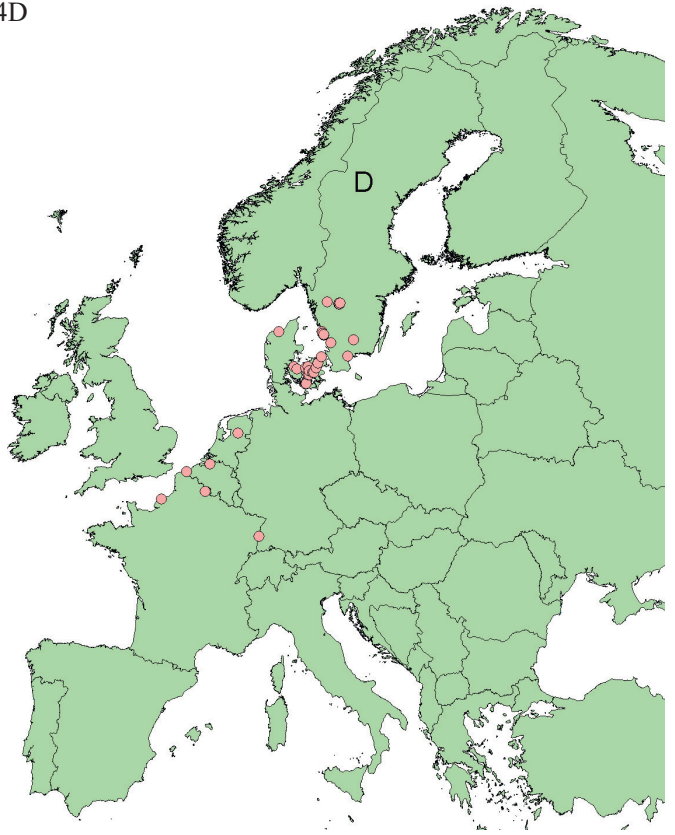

Aterfynd av grågäss märkta i olika delar av Sverige (se Figur 1): $A=$ Skåne, $B=$ Gotland, $C=$ Småland, $D=$ Västra Götaland, $E=$ Södermanland, $F=$ Stockholms skärgård, $G=$ Hälsingland and $H=$ Jämtland. Tre fynd saknas på kartorna: två fåglar från Gotland återfanns i Tunisien och en från Södermanland rapporterades från Algeriet 

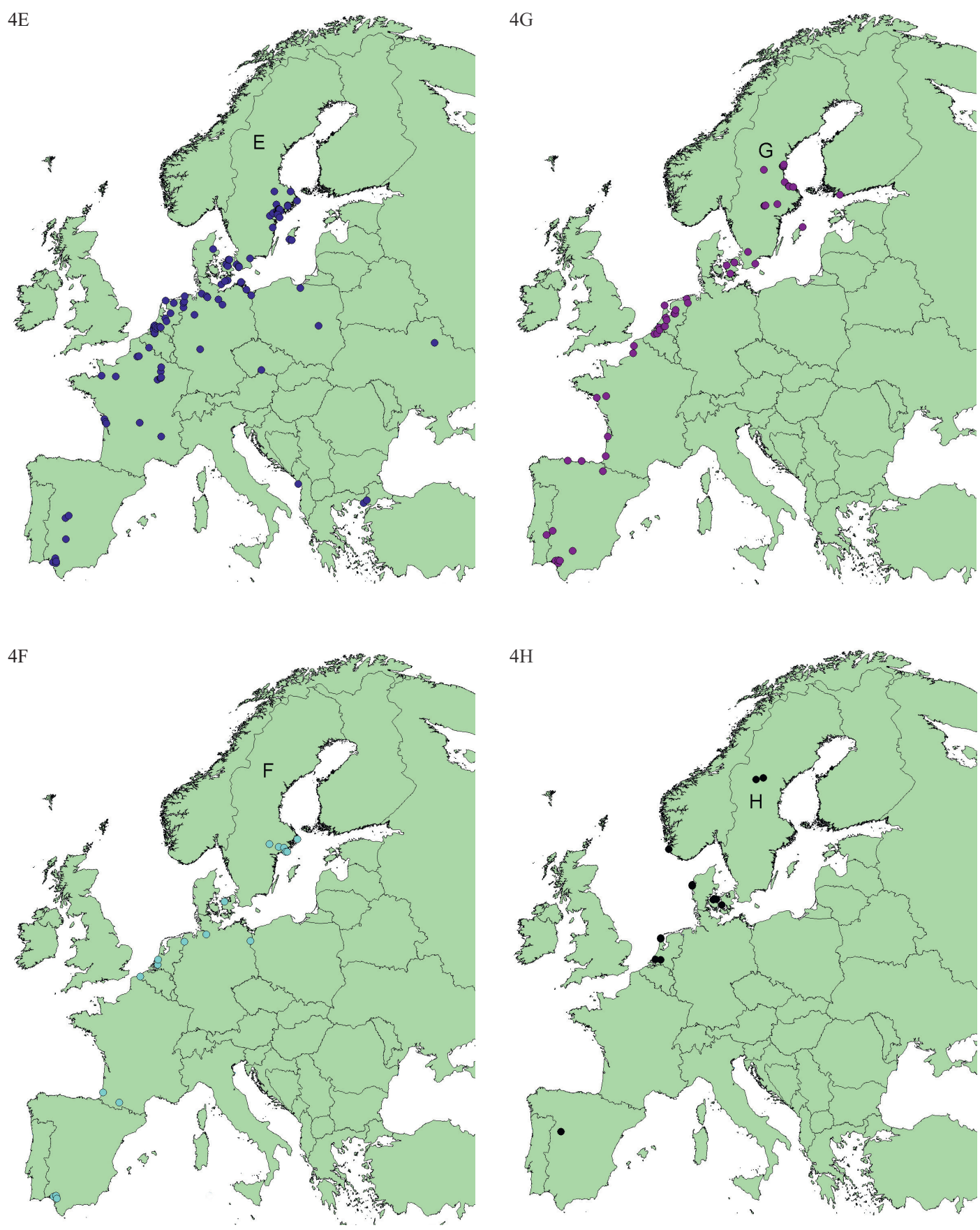
illustrated by the total dataset from the neck-banded Greylag Geese from SW Scania. Comparing the neckband resightings with the traditional recoveries from geese marked in the same area, there are some differences mainly relating to differences in the hunting pressure which makes it more difficult to use the traditional recoveries for an analysis of changes in the migration. Thus $11 \%$ of the traditional recoveries of geese marked in Scania were reported from France, whereas about $5 \%$ of neck-banded Greylags were re-sighted in France. In the Netherlands the number of resightings of neck-banded Greylag Geese was high, whereas the number of traditional recoveries was lower.

On the island of Gotland, most ringed Greylag Geese were caught during the moult especially as part of a special study during the years 1965-1975 (von Essen 1982). The majority of the ringed geese followed the same route along the east Atlantic coast south to Spain as the geese from Scania (Figure 4B) but a large proportion was apparently of east European origin as they migrated south through eastern Europe. Two recoveries of these birds (not shown on the map) were from Tunisia. In all about $25 \%$ of the recoveries were from the Central European Flyway.

Twenty-five recoveries of Greylag Geese ringed in the province of Småland (Figure 4C) were reported. All of them except three (two from Poland and one from Slovenia) were reported from the Western flyway. The Western flyway was also used by all thirty-eight birds from Västra Götaland that were recovered (Figure 4D). In contrast to the recoveries from the other marking areas, all recoveries from Västra Götaland were from the northern part of the flyway with a concentration to Denmark, and the southernmost records being reported from northern France.

The third largest number of recoveries came from the markings in the province of Södermanland (Figure 4E). The material from this province is highly dominated by an introduced population established around Öster-Malma (cf. Andersson et al. 2001). The majority of the Greylag Geese from this group were recovered from the Western flyway with a good number of recoveries from all countries in this flyway. In contrast to the geese from most other marking areas except Småland, a number of recoveries from areas further to the east were reported with recoveries both from Poland, Ukraine, Croatia and Turkey. Whereas the recoveries from the Western flyway mostly were concentrated to the coasts for geese from the other marking areas, a higher proportion of the geese from Södermanland were recovered also in inland France. One important area for the geese from this marking area was Lac du Der in Northeast France. As was also found by observations of neck-banded geese (Andersson et al. 2001), Öster-Malma birds had established a wintering tradition in the Lac Du Der area in northern France yielding a large number of neckband readings.

Twenty-three Greylag Geese were marked in the Stockholm archipelago (Figure 4F), all of these being recovered in the Western flyway with the exception of one recovery from the border between German and Poland.

Quite a large number of Greylag Geese were ringed in the province of Hälsingland (Figure 4G) producing 68 recoveries, all from the Western flyway with the exception of one recovery from the island of Gotland and one from southern Finland. A small sample of geese marked in the inland province of Jämtland (Figure $4 \mathrm{H}$ ) showed generally the same pattern but with one recovery each from southwest Norway and western Denmark.

\section{Discussion}

When comparing the traditional recoveries of Greylag Geese with the observations reported on sightings of neck-banded Greylag Geese in the West European flyway, some marked differences in the distribution of recoveries and resightings between different countries were noted. In the neck-banding data, observations from the Netherlands dominated markedly in the reports, whereas records of neckband sightings from France were much more sparse (Andersson et al. 2001, Nilsson et al. 2013). On the other hand, the number of traditional recoveries of shot birds was only slightly lower in France than in the Netherlands and Denmark. The high number of recoveries from France compared to the other countries reflect the higher hunting pressure on geese here compared to countries further north (cf. also Nilsson et al. 2013).

Another factor to be kept in mind when comparing the traditional recoveries with the observation of neck-banded Greylag Geese is the marked changes in the migration patterns and wintering distribution of the species which has taken place during recent decades (Nilsson 2006, Ramo et al. 2015). In most cases the number of traditional recoveries are too small to make it meaningful to separate recoveries from different time periods, but this change in general migration pattern must be kept in mind when discussing the picture obtained from the traditional recoveries from different regions over a long run of years.

Comparing the general picture of the migration habits of Greylag Geese from Scania obtained from the observations of neck-banded individuals with recoveries from the traditional marking in Scania, they show largely similar patterns. There are however 
some differences mainly related to differences in hunting pressure between different countries as presented above.

Whereas the general picture from the two datasets are quite similar for Greylag Geese from Scania, there are some differences in details for the geese from Södermanland and Gotland. In the map for recoveries of Greylag Geese from Södermanland there are a few records from Lac du Der (Figure 4F) but the concentration of geese from Södermanland here does not show up so clearly as in the observations of neck-banded Greylag Geese from the same area. This may be an effect of the central parts of the Lac du Der area being protected. Moreover, there were intensive neckband reading operations in the area. The traditional ring recoveries from the Södermanland bird are also fairly well distributed all the way south through France and Spain, whereas relatively few neckband readings of Södermanland birds were obtained from this area (Andersson et al. 2001, Nilsson et al. 2013). In contrast to the neckband readings a number of traditional recoveries were reported from Eastern Europe as far east as Turkey, whereas the neck-banded geese were found in the Western flyway (Andersson et al. 2001).

The samples from Gotland also show differences between the neck-banded birds and the ring-recoveries. Whereas only four individuals neck-banded on Gotland were reported from the Central European Flyway, about $25 \%$ of the traditional recoveries of Greylag Geese marked on Gotland were recovered from the Central European Flyway. These differences might be explained by the different time-spans of the datasets and changes in the migration patterns of Greylag Geese during recent decades (cf. Nilsson 2006). Most traditional recoveries were from birds ringed in 1965-1975 (von Essen 1982), whereas neck-banding on Gotland was made during a few years in the eighties (Andersson et al. 2001).

In conclusion, the traditional recoveries show the same general migration pattern for the Greylag Geese as the observations of neck-banded geese even if there are some differences in the distribution of sightings and recoveries such as the higher frequency of recoveries compared to sightings for France related to the higher hunting pressure on geese in France compared to other countries. The Greylag Geese from two areas showed that part of the geese migrated in more easterly directions than the majority of the Swedish Greylag Geese, some birds form Södermanland were spread over Eastern Europe. Moreover several recoveries of Greylag Geese marked on Gotland migrated south through Eastern Europe. As found by von Essen (1982) the moulting sites on Gotland attracted Greylag Geese from Eastern Europe. After moult, these birds probably returned to their areas of origin and migrated south with the local Eastern European birds.

\section{References}

Andersson, Å., Follestad, A., Nilsson, L. \& Persson, H. 2001. Migration patterns of Nordic Greylag Geese Anser anser. Ornis Svecica 11: 19-58.

Essen, L. von 1982. De ruggande grågässen på Gotland. Vår Fågelvärld Suppl. 9: 45-52.

Fransson,T. \& Pettersson, J. 2001. Svensk Ringmärkningsatlas. Vol 1. Stockholm.

Nilsson, L. 2006. Changes in migration patterns and wintering areas of south Swedish Greylag Geese Anser anser. Pp. 514-516 in Waterbirds around the World (G.C. Boere, C.A. Galbraith \& D.A. Stroud, eds.). The Stationary Office, Edinburgh, UK.

Nilsson, L., Follestad, A., Guillemain, M., Schricke, V. \& Voslamber, B. 2013. France as a staging and wintering area for Greylag Geese Anser anser. Wildfowl 63: 24-39.

Ramo,C,. Amat, J.A., Nilsson,L., Schricke,V., RodriguezAlonso,M., Gomez-Crespo,E., Jubete, F., Navedo,J.S., Masero,J.A., Palacios,J., Boos,M., Green,A.J. 2015. Latitudinal-Related Variation in Wintering Population Trends of Greylag Geese (Anser Anser) along the Atlatic Flyway: A Response to Climate Change? Plos one 10(10): e0140181.

\section{Sammanfattning}

Under senare år har grågåsens flyttningsvanor studerats intensivt $\mathrm{i}$ ett flertal europeiska länder med hjälp av märkning av gässen med halsringar. I de nordiska länderna startade detta 1984 (Andersson et al. 2001). Halsmärkningarna av grågäss i Sverige har i huvudsak koncentrerats till tre områden: SW Skåne, ÖsterMalma i Södermanland och Gotland. Därutöver har genom åren ett betydande antal grågäss märkts med Ringmärkningscentralens ringar (Fransson \& Pettersson 2001). I denna uppsats analyserar jag de traditionella ringåterfynden för grågäss för att komplettera den bild halsmärkningen givit med information om flyttningsvanorna hos grågäss från andra delar av landet.

I min analys har jag använt återfynd rapporterade till och med 2012. Fram till detta år märktes 7210 grågäss som givit 1398 återfynd (19,4\%), varav 924 återfynd återstår när lokala fynd uteslutits. Jag har här jämfört fördelningen av återfynd från åtta olika områden i landet, vilka visas på kartan i Figur 1.

Av de 924 återfynden rapporterades 157 från Sverige (Figur 2). De flesta återfynden kommer från västra Europa där gässen flyttar nära Atlantkusten till vinterområdena som tidigare låg i Spanien. Man kan notera förhållandevis små skillnader i antalet rapporterade återfynd från de olika länderna, vilket står i kontrast till rapporteringen av halsmärkta gäss från dessa län- 
der. Förklaringen till detta torde kunna sökas i olika hårt jakttryck på gäss, där speciellt Frankrike ligger högt. Däremot visar den tidsmässiga fördelningen av återfynden betydande likheter med motsvarande bild från observationerna av halsmärkta gäss (Figur 3).

Återfyndens fördelning på olika länder för de olika märkområdena framgår av Figur 4. Majoriteten av återfynden följde den västeuropeiska flyttningskorridoren, men gäss från några märkområden återfanns också från andra delar av Europa, vartill kommer ett återfynd från Algeriet och två från Tunisien. En del av gässen från Södermanland (Figur 4E) gav återfynd spridda över östra Europa, men merparten sågs i västra Europa, där observationerna av halsmärkta grågäss visade att bl.a. ett område, Lac du Der, i norra Frankrike var viktigt för gäss från Öster-Malma (Andersson et al. 2001).

Grågässen från Gotland visar en avvikande bild, men till skillnad från övriga märkta gäss var merparten av dessa märkta som ruggare (von Essen 1982) och de gotländska ruggningslokalerna rekryterade i betydande utsträckning ruggare från östra Europa. 